\title{
The Formation of the Christian Bible
}

\author{
HaNs von Campenhausen, D.D., F.B.A.
}

Described by Dr Henry Chadwick as 'the greatest work of a master', this is the classic modern presentation of a major but strangely neglected subject in historical theology. The author's account of how and why Christians developed the idea of having their own authoritative corpus of sacred scripture is the finest of his many distinguished contributions to the history of early Christianity, and one with the widest appeal to all students of the Bible. He describes the relation of the Church to the traditional Old Testament, the emergence of the New Testament and the earliest theological interpretations of the whole Bible. Translated by J. A. Baker, Fellow of Corpus Christi College, Oxford.

December $£ 3.75$ net

\section{A Commentary on The First and Second Epistles to the Thessalonians}

\author{
ERNEST BEST, PH.D.
}

For sixty years there has been no substantial new commentary in English, or in German, on Paul's Thessalonian letters. Dr Best has therefore ranged widely over the many special studies published on different aspects of the subject since early in the century. His introduction describes Thessalonica and Paul's visit to the city, discusses the occasion and purpose of the first epistle with its authenticity and integrity, and then deals in detail with the problem raised by differences in the second letter and in some of its teaching. A final chapter is concerned with the eschatological themes of the epistles and some of the issues arising from these. Dr Best is Senior Lecturer in Biblical Literature and Theology at St Andrews. Black's New Testament Commentaries

Cased $£ 4.00$ net: paperback $£ 2.50$ net

\section{ADAM \& CHARLES BLACK}




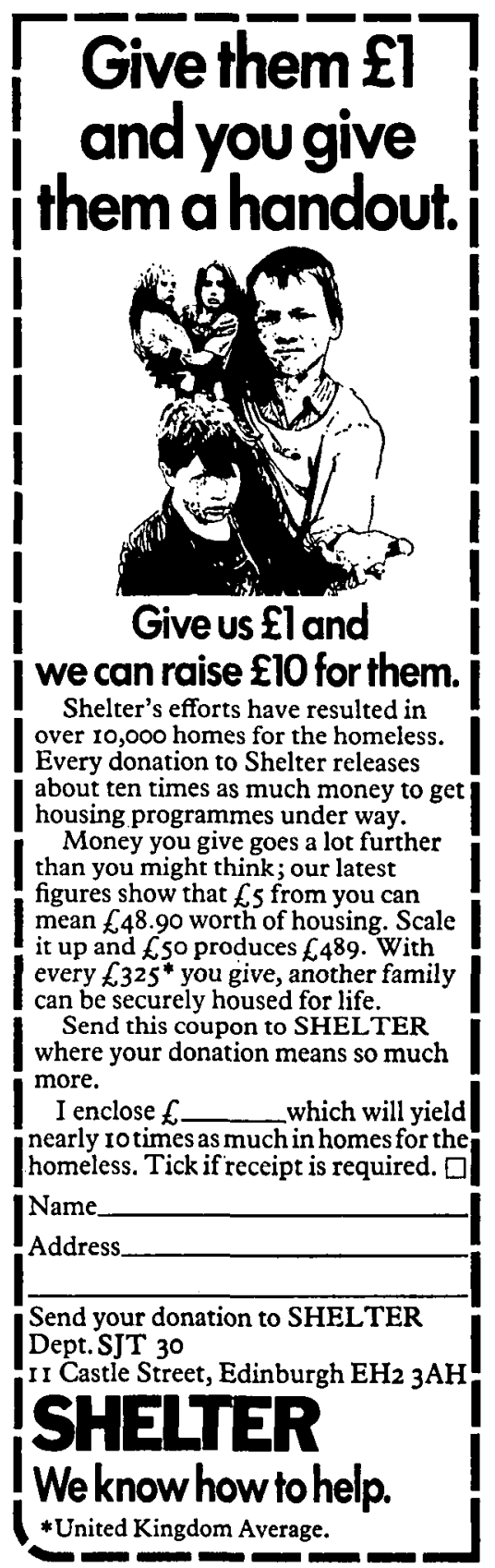




\title{
FREE UNIVERSITY OF AMSTERDAM
}

\author{
At the Faculty of Theology \\ there will arise at the first of \\ September 1973, because of \\ the super-annuation of \\ Prof. dr. G. C. Berkouwer, \\ a vacancy for a
}

\section{professor}

in Dogmatics, History of Dogma and Symbolism.

Those who are interested in this position and those who want to call the attention to other possible applicants, are invited to apply to the Dean of the Faculty of Theology, De Boelelaan 1105, P.O. box 7161, AmsterdamBuitenveldert. 
Contributions and editorial correspondence should be sent to one of the editors: Rev. Professor T. F. Torrance, 37 Braid Farm Road, Edinburgh, zhio 6le, Scotland; Rev. Professor J. K. S. Reid, Don House, 46 Don Street, Aberdeen, AB2 IUU, Scotland.

Submission of an article is taken to imply that it has not previously been published in English, or is not being considered by another journal for publication in English. In the interests of authors, copyright is normally assigned to the Cambridge University Press. The average length of articles is 5000 words. Although longer articles are accepted, those in excess of 10,000 words cannot be considered.

Contributions (articles and reviews) should be clearly typed in double spacing, and on one side of the paper only. The rule about double spacing applies also to footnotes, which should be used sparingly. Cross-references within the article offered should not be included.

Notes for the editors and instructions for the printer should be attached on separate sheets. Contributors should keep one copy of the typescript for use in correcting proofs.

Contributors from the United States may use U.S. spellings. Greek and Hebrew words need not be transliterated. Capitalisation should be kept to a minimum; and in particular should not be used in pronouns referring to the Deity.

First proofs of articles and article reviews may be read and corrected by contributors, and should normally be returned to the organising editor within ten days of receipt. Correction should be confined to errors of the printer. More extensive correction can be made only with the concurrence of an editor. No proofs of reviews will be sent.

Contributors of articles and article reviews (but not of reviews) receive 25 free offprints. Extra copies may be bought according to an agreed scale of charges, provided that these are ordered at the time of returning corrected proofs.

\section{PERMISSIONS}

For permission to reproduce material from Scottish Journal of Theology please apply to the London or New York office of Cambridge University Press. 


\section{CONTENTS}

Pneumatology and process theology, by H. F. WoOdHouse (Dublin)

Mysterium fidei and the later Calvin, by JoHn R. MEYer (Hamilton, Ontario)

Gospel law and freedom in the theological ethics of Karl Barth, by SwON H. RAE (Bandiong, Indonesia)

Some studies of New Testament diakonia, by C. TATtoN

(Birmingham)

Article review of Alastair McKinnon: Falsification and

Belief, by Thomas F. Torrance (Edinburgh)

\section{REVIEWS}

sYkes and Cl.AYton (eds.):

Christ, Faith and History

wrLlas of оскнам: Opera Philosophica et Theologica

marston: Quodlibeta quatuor 46 t

BARTH: Fragments Grave and Gay 462

BALTENSWEILER and REICKe (eds.):

Neues Testament und

Geschichte

WHELAN: The Spirituality of

Friedrich von Hügel

ansunNo: Baron Friedrich von

Hugel and the Modernist Crisis in England

TERLHARD DE CHARDIN: Christianity and Evolution. DAvEs: Beginning

Now. morrason: Man Does Not

Stand Alone

o'colLINs: Foundations of Theology

marvenue: The Narrative Style of the Pricatly Writer

haverzoshand: The Book of Amos:

A Commentary

schronar: Der Markus-Stoff bei Lukas

TAYror: The Passion Narrative of St Luke: A Critical and

Hintoric Inveatigation

Hanchen: The Acts of the Apoutles

anseour: Traditio-Historical Criticism of the Gospels. rULLER: The Formation of the Resurrection Narratives
SCHWEIZER: Jeaus

478

akvenot: Cyprian: De Lapais and De Bcclesiae Catholicae Unitate

LLLA: Clement of Alexandria

yatheson: Cardinal Contarini at Regensburg

coOdall: Bcumenical Progrem, a decade of change in the Bcumenical Movement 1961-1971. pouYns: Orthodoxy, Roman Catholicim and Anglicaniam $\quad \mathbf{4 5}$

Multilateral Church Conversation in Scotland

Asuruser and LAsesos: Handbuch der Religionsgeschichte, Band I 490

HANBon: Groundwork for Unity. renton: What was Jesus' Mesange? warren: A Theology of Attention

GEYrR and pezrunv: Theological Cromings

Hagemen and WHEaton (eds.): Religion in Cuba Today

DAve: Christ and the World Religions

Barclay: Ethics in a Perminive Society. macoonnLd: Criais of Belief. wornns: Maurice Man and Moralist

476 Doore necerved 